\title{
BUSINESS INTELLIGENCE SYSTEM ADOPTION: A SYSTEMATIC LITERATURE REVIEW OF TWO DECADES
}

\author{
Chi Tin Wong ${ }^{1 *}$, Cheng Ling Tan ${ }^{1}$ and Imran Mahmud ${ }^{2}$ \\ ${ }^{1}$ Graduate School of Business, Universiti Sains Malaysia, Penang, Malaysia \\ 2Department of Information Technology \& Management, Daffodil International University, Bangladesh
}

ABSTRACT - The rapid development of Artificial Intelligence (Al) in recent years has greatly improved humans' quality of life and promoted Information Systems (IS) development progress. Business Intelligence (BI) system is one of the tools in the field of IS which obtained benefits from the development of Al. The adoption of BI can enhance the competitive aspect of a business organization in today's high competitive business environment and play an important role in determining a business organization's success. However, literature shows that the adoption rate of $\mathrm{Bl}$ system is low and it is predicted that the adoption rate will not increase a lot in near future. Prior research studies paid less attention in comprehensive study that review research articles related to $\mathrm{Bl}$ system adoption in regard to discuss the issues and research gaps. There is an absence of a clear agenda or roadmap in the research area of Bl adoption. Therefore, this study aims to synthesize and analyze research studies of $B I$ adoption in the past two decades, identify the major theories that researchers have used to predict the adoption of BI, and summarize key antecedents that influence the adoption of $B I$. This study reviewed 44 research articles published on the adoption of BI between the year 2000 and the first quarter of 2020. The findings first indicate that the analysis of $\mathrm{Bl}$ adoption literature is not comprehensive enough. Researchers in the past two decades commonly rely on TAM and its modifications to measure the adoption of BI. The finding also indicates that there are limited research studies on negative stimulus of BI adoption. This study proposes the agenda for continued research in the area of $B I$ adoption that targets identified gaps in the literature.
ARTICLE HISTORY

Received:13-4-2020

Accepted:3-6-2020

\section{KEYWORDS}

Systematic literature

review

Business intelligence

system

Adoption

Adoption intention

BI

\section{INTRODUCTION}

The rapid development of Artificial Intelligence (AI) in recent years has greatly improved humans' quality of life and promoted Information Systems (IS) development progress. Business Intelligence (BI) system is one of the tools in the field of IS which obtained benefits from the development of AI (Torres et al., 2018). It is equipped with different latest intelligence algorithms that allow decision-makers to convert data into useful information to support the decision made, make a decision in a short period of time, and enhance the correctness of the decision made when comparing to the old days (Popovič et al., 2019). Therefore, the adoption of BI can enhance the competitive aspect of a business organization in today's highly competitive business environment and it plays an important role in determining a business organization's success.

However, the literature shows that the adoption rate of the BI system is low and it is predicted that the adoption rate will not increase a lot in near future (Dresner Advisory Services, 2017; Dresner Advisory Services, 2018). Prior research studies paid less attention to a comprehensive study that review research articles related to BI system adoption in regard to discuss the issues and research gaps (Richards et al., 2019; Lautenbach et al., 2017; Foshay et al., 2014). There is an absence of a clear agenda or roadmap in the research area of BI adoption. Therefore, this study aims to synthesize and analyze research studies of BI adoption in the past two decades, identify the major theories that researchers have used to predict the adoption of BI, and summarize key antecedents that influence the adoption of BI.

\section{REVIEW METHODOLOGY}

This study reviewed the literature on the adoption of BI between the year 2000 and the first quarter of 2020 from various databases such as Science Direct, IEEE Xplore, Taylor \& Francis Online, Emerald insight, EBSCOhost, JSTOR Archive, ProQuest, Web of Science, Wiley Online Library, Springer-Link and Sage Journal with the keywords "Business Intelligence", "Business Intelligence system", "BI", "Business Intelligence adoption", "use of Business Intelligence", "adoption intention" and "acceptance". Scopus and Google Scholar search engines were also adopted in order to ensure wide coverage of publications. Research studies related to BI adoption and adoption intention were both included because behavior intention and its predictors have an influence on the actual adoption, and the intention is one of the antecedents that influence adoption. This study considered different types of English language publications (working papers, conference papers, and peer-reviewed journal publications). There is a total of 96 articles related to the BI adoption 
published between the year 2000 and the first quarter of 2020. The content of these articles was studied carefully to see whether it is relevant to BI adoption, and 52 articles were omitted because the research direction of these studies was not on BI adoption or focused on other enterprise systems. Finally, there is a total of 44 articles were selected for further analysis.

\section{FINDINGS AND DISCUSSION}

\section{Main theories}

There are about 44 research studies in the past two decades related to BI adoption, and researchers suggested a lot of information technology adoption theories on the BI system. Table 1 illustrates the theories used in BI adoption in past decades such as Technology Acceptance Model (TAM) (34\%) by Davis et al. (1989), Diffusion of Innovation theory (DOI) (22.7\%) by Rogers (1962), Resource-based view (RBV) (9\%) by Barney (1991), Unified Theory of Acceptance and Use of Technology (UTAUT) (6.8\%) by Venkatesh et al. (2003) and Technology, Organization, Environment theory (TOE) $(6.8 \%)$ by Tornatzky and Fleischer (1990). Apart from using a single theory to explain the BI adoption, researchers also tried to integrate multiple technology acceptance theories with theories from psychology, marketing, and social science domain such as Theory of Planned Behaviour (TPB), Social Exchange Theory (SET), Expectancy Theory (ET) and Theory of Reasoned Action (TRA).

Table 1. Articles included in the review

\begin{tabular}{|c|c|c|c|c|}
\hline No & Author(s) & Theories & Factors & $\begin{array}{l}\text { Countries and } \\
\text { Sampling }\end{array}$ \\
\hline 1 & Bach et al. (2016) & TAM & $\begin{array}{l}\text { "Perceived Usefulness of BIS; Perceived } \\
\text { Ease of Implementation of BIS; } \\
\text { Technology-Driven Strategy; Information } \\
\text { Quality; IT Project Management; Change } \\
\text { Management; Knowledge Sharing" }\end{array}$ & USA (100) \\
\hline $2 *$ & Brockmann et al. (2012) & TAM & $\begin{array}{l}\text { "Perceived Value; Perceived Ease of Use; } \\
\text { Trust; Perceived Ease of Adoption" }\end{array}$ & Germany (-) \\
\hline $3 *$ & Chang et al. (2014) & TAM & $\begin{array}{l}\text { "Perceived Ease of Use to Read; Perceived } \\
\text { Usefulness; Perceived Ease of Use to } \\
\text { Create" }\end{array}$ & $\begin{array}{l}\text { China (118) } \\
\text { Taiwan (153) }\end{array}$ \\
\hline 4 & Foshay et al. (2014) & TAM & $\begin{array}{l}\text { "Definitional Metadata Quality; Data } \\
\text { Quality Metadata Quality; Navigational } \\
\text { Metadata Quality; Lineage Metadata } \\
\text { Quality; Perceived Usefulness; Perceived } \\
\text { Ease of Use" }\end{array}$ & $\begin{array}{l}\text { North American } \\
\text { (499) }\end{array}$ \\
\hline 5 & Gorla et al. (2003) & TAM & $\begin{array}{l}\text { "Visualization; Summarization; } \\
\text { Navigation; Query; Sophisticated Analysis; } \\
\text { Dimensionality; Performance; Ease of Use; } \\
\text { Usefulness" }\end{array}$ & Hong Kong (58) \\
\hline 6 & Grublješič et al. (2014) & $\begin{array}{l}\text { TAM } \\
\text { UTAT }\end{array}$ & $\begin{array}{l}\text { "Effort Perceptions; Performance } \\
\text { Perceptions; Social Influence; Result } \\
\text { Demonstrability; Facilitating Conditions; } \\
\text { Focus on Customer" }\end{array}$ & EU (195) \\
\hline $7 *$ & Hart et al. (2007) & TAM & $\begin{array}{l}\text { "Job Relevance; Output Quality; Result } \\
\text { Demonstrability; Anxiety; Facilitating } \\
\text { Conditions; Perceived Usefulness; } \\
\text { Perceived Ease of Use" }\end{array}$ & South Africa (53) \\
\hline 8 & Hart and Porter (2004) & TAM & $\begin{array}{l}\text { "Result Demonstrability; Output Quality; } \\
\text { Job Relevance; Perceived Usefulness; } \\
\text { Perceived Ease of Use" }\end{array}$ & South Africa (65) \\
\hline 9 & Hong et al. (2006) & TAM & $\begin{array}{l}\text { "Data Quality; Accessibility; Response } \\
\text { Time; Support and Training; Perceived } \\
\text { Usefulness; Perceived Ease of Use; } \\
\text { Perceived Individual Impact" }\end{array}$ & Korea (115) \\
\hline 10 & Hou (2013) & $\begin{array}{l}\text { TAM } \\
\text { TPB }\end{array}$ & $\begin{array}{l}\text { "Perceived Usefulness; Perceived Ease of } \\
\text { Use; Compatibility; Peers' Influence; } \\
\text { Supervisors' Influence; Self-efficacy; } \\
\text { Facilitating Condition"' }\end{array}$ & Taiwan (339) \\
\hline 11 & Hou (2015) & $\begin{array}{l}\text { TAM } \\
\text { ECMoIS }\end{array}$ & $\begin{array}{l}\text { "Perceived Usefulness; Confirmation of } \\
\text { Expectation; Perceived Ease of Use; } \\
\text { Satisfaction" }\end{array}$ & Taiwan (330) \\
\hline
\end{tabular}




\begin{tabular}{|c|c|c|c|c|}
\hline No & Author(s) & Theories & Factors & $\begin{array}{l}\text { Countries and } \\
\text { Sampling }\end{array}$ \\
\hline $12 *$ & Jiang (2009) & $\begin{array}{l}\text { TAM } \\
\text { MT } \\
\text { DOI }\end{array}$ & $\begin{array}{l}\text { "Perceived Usefulness; Perceived Ease of } \\
\text { Use; Social Influence; External Controls; } \\
\text { User Predisposition" }\end{array}$ & Taiwan (-) \\
\hline $13 *$ & Kohnke (2011) & TAM & $\begin{array}{l}\text { "Quality of Information; System } \\
\text { Performance; User Information; User } \\
\text { Training; Top Management Support; } \\
\text { Subjective Norm; Perceived Usefulness; } \\
\text { Perceived Ease of Use" }\end{array}$ & Brazil (258) \\
\hline 14 & $\begin{array}{l}\text { Ramamurthy et al. } \\
(2008)\end{array}$ & $\begin{array}{l}\text { TAM } \\
\text { DOI }\end{array}$ & $\begin{array}{l}\text { "Relative Advantages; Complexity; } \\
\text { Organizational Commitment; Absorptive } \\
\text { Capacity; Organizational Size; } \\
\text { Organizational Scope; Organizational Data } \\
\text { Environment" }\end{array}$ & USA (198) \\
\hline 15 & Zhao et al. (2012) & TAM & $\begin{array}{l}\text { "Organizational Use Satisfaction; } \\
\text { Organizational Needs; Organizational } \\
\text { Readiness; Organizational Variables; } \\
\text { Provider Variables; System Variables; } \\
\text { Project Variables" }\end{array}$ & USA (-) \\
\hline 16 & Ahmad et al. (2016) & DOI & $\begin{array}{l}\text { "Relative Advantage; Complexity; } \\
\text { Compatibility; Triability; Observability" }\end{array}$ & Malaysia (310) \\
\hline 17 & $\begin{array}{l}\text { Boonsiritomachai et al. } \\
\text { (2016) }\end{array}$ & DOI & $\begin{array}{l}\text { "Relative Advantages; Complexity; } \\
\text { Compatibility; Absorptive Capacity; } \\
\text { Organisational Resource Availability; } \\
\text { Competitive Pressure; Vendor Selection; } \\
\text { Owner-manager's Innovativeness; Owner- } \\
\text { manager's IT Knowledge" }\end{array}$ & Thai (427) \\
\hline 18 & Jaklič et al. (2018) & $\begin{array}{l}\text { DOI } \\
\text { RBV } \\
\text { UTAT }\end{array}$ & $\begin{array}{l}\text { "Performance Perceptions; Compatibility; } \\
\text { Result Demonstrability; Social Influence" }\end{array}$ & EU (195) \\
\hline 19 & Lautenbach et al. (2017) & $\begin{array}{l}\text { DOI } \\
\text { TOE }\end{array}$ & $\begin{array}{l}\text { "Data Infrastructure Capabilities; Data } \\
\text { Management Challenges; Top } \\
\text { Management Support; Talent Management } \\
\text { Challenges; External Market Influence; } \\
\text { Regulatory Compliance" }\end{array}$ & South Africa (72) \\
\hline 20 & Popovič et al. (2019) & DOI & $\begin{array}{l}\text { "Impact on Marketing and Sales; Impact on } \\
\text { Management and Internal Operations; } \\
\text { Impact in Firm Procurement; Impact on } \\
\text { Firm Performance" }\end{array}$ & Portugal (181) \\
\hline 21 & Puklavec et al. (2014) & $\begin{array}{l}\text { DOI } \\
\text { TOE }\end{array}$ & $\begin{array}{l}\text { "Expected Benefits; Perception of Strategic } \\
\text { Value; Cost; BIS is a part of ERP; } \\
\text { Management Support; Organizational } \\
\text { Culture; Project Champion; Organizational } \\
\text { Data Environment; Organizational } \\
\text { Readiness; Size; External Support" }\end{array}$ & Slovenia (-) \\
\hline 22 & Puklavec et al. (2017) & $\begin{array}{l}\text { DOI } \\
\text { TOE }\end{array}$ & $\begin{array}{l}\text { "Expected Benefits; Perception of Strategic } \\
\text { Value; Cost; BIS is a part of ERP; } \\
\text { Management Support; Rational Decision } \\
\text { Making Culture; Project Champion; } \\
\text { Organizational Data Environment; } \\
\text { Organizational Readiness; External } \\
\text { Support" }\end{array}$ & Slovenia (181) \\
\hline $23 *$ & Yoon et al. (2014) & $\begin{array}{l}\text { DOI } \\
\text { TPB } \\
\text { MT }\end{array}$ & $\begin{array}{l}\text { "Relative Advantages; Complexity; } \\
\text { Compatibility; Intrinsic Motivation; } \\
\text { Extrinsic Motivation; Supervisor Support; } \\
\text { Co-worker Support; Requisite Skills \& } \\
\text { Resources; Organizational Learning } \\
\text { Climate" }\end{array}$ & USA (47) \\
\hline 24 & Arefin et al. (2015) & $\begin{array}{l}\text { RBV } \\
\text { ISCM }\end{array}$ & $\begin{array}{l}\text { "Organizational Strategy; Organizational } \\
\text { Structure; Organizational Process; } \\
\text { Organizational Culture; System }\end{array}$ & Bangladesh (225) \\
\hline
\end{tabular}




\begin{tabular}{|c|c|c|c|c|}
\hline No & Author(s) & Theories & Factors & $\begin{array}{c}\text { Countries and } \\
\text { Sampling } \\
\end{array}$ \\
\hline $25^{*}$ & Fink et al. (2017) & RBV & $\begin{array}{l}\text { Effectiveness; Organizational } \\
\text { Effectiveness" } \\
\text { "Exploitation; Exploration; BI Team; BI } \\
\text { infrastructure; Operational BI Capabilities; } \\
\text { Strategic BI Capabilities; Operational } \\
\text { Business Value; Strategic Business Value" }\end{array}$ & Israel (159) \\
\hline $26^{*}$ & Torres et al. (2018) & $\begin{array}{l}\text { RBV } \\
\text { IPT }\end{array}$ & $\begin{array}{l}\text { "Infrastructure Quality; Management } \\
\text { Capability; Personnel Expertise" }\end{array}$ & UK (137) \\
\hline 27 & Hou (2014) & UTAT & $\begin{array}{l}\text { "Performance Expectancy; Effort } \\
\text { Expectancy; Social Influence; Facilitating } \\
\text { Conditions; Gender; Age; Experience; } \\
\text { Voluntariness of Use" }\end{array}$ & Taiwan (330) \\
\hline $28 *$ & Li et al. (2013) & MT & $\begin{array}{l}\text { "Perceived Usefulness; Intrinsic } \\
\text { Motivation toward Accomplishment; } \\
\text { Intrinsic Motivation to Know; Intrinsic } \\
\text { Motivation to Experience Stimulation; } \\
\text { Personal Innovativeness with IT" }\end{array}$ & China (193) \\
\hline $29 *$ & Richards et al. (2019) & $\begin{array}{l}\text { IPT } \\
\text { IMoITV }\end{array}$ & $\begin{array}{l}\text { "BIS Effectiveness; Business Analytics } \\
\text { Effectiveness; Planning Effectiveness; } \\
\text { Measurement Effectiveness; Process } \\
\text { Effectiveness" }\end{array}$ & Canada (337) \\
\hline $30 *$ & Han et al. (2016) & ECMoIS & $\begin{array}{l}\text { "Confirmation; Perceived Usefulness; } \\
\text { Satisfaction; Habit; Psychological } \\
\text { Empowerment; Structural Empowerment" }\end{array}$ & Taiwan (117) \\
\hline $31 *$ & Chang et al. (2017) & $\mathrm{BDB}$ & $\begin{array}{l}\text { "Conscientiousness; Emotional Stability; } \\
\text { Agreeableness; Extraversion; Openness to } \\
\text { Experience" }\end{array}$ & $\begin{array}{l}\text { China \&Taiwan } \\
(354)\end{array}$ \\
\hline $32 *$ & Chang et al. (2015) & $\begin{array}{l}\text { BDB } \\
\text { ET } \\
\text { SET }\end{array}$ & $\begin{array}{l}\text { "Tangible Rewards; Intangible Rewards; } \\
\text { Organization Rewards; Reputation } \\
\text { Reciprocity" }\end{array}$ & China (271) \\
\hline 33 & Arnott et al. (2017) & GSM & $\begin{array}{l}\text { "Operational Control; Management } \\
\text { Control; Strategic Planning" }\end{array}$ & Australia (-) \\
\hline $34 *$ & Işık et al. (2013) & GSM & $\begin{array}{l}\text { "Data Quality; Integration with other } \\
\text { System; User Access; Flexibility; Risk } \\
\text { Management Support; Decision Types; } \\
\text { Information Processing Needs" }\end{array}$ & USA (92) \\
\hline $35^{*}$ & Kositanurit et al. (2011) & TPC & $\begin{array}{l}\text { "System Quality; Information Quality; } \\
\text { Utilization; Performance" }\end{array}$ & $\begin{array}{l}\text { USA (349) } \\
\text { Thai (304) }\end{array}$ \\
\hline $36^{*}$ & Hou (2012) & NNM & $\begin{array}{l}\text { "Content; Accuracy; Format; Ease of Use; } \\
\text { Timeliness" }\end{array}$ & Taiwan (330) \\
\hline $37 *$ & Trieu (2013) & $\begin{array}{l}\text { TEU } \\
\text { WWF }\end{array}$ & $\begin{array}{l}\text { "Data Integration; BI Interaction } \\
\text { Transparency; BI Representational } \\
\text { Fidelity; Informed Decision; Decision- } \\
\text { Making Effectiveness; Decision-Making } \\
\text { Efficiency" }\end{array}$ & Australia (-) \\
\hline $38 *$ & Elbashir et al. (2008) & VCAFP & $\begin{array}{l}\text { "Customers Intelligence; Supplier } \\
\text { Relations; Internal Efficiency; Business } \\
\text { Process Performance; Organizational } \\
\text { Performance" }\end{array}$ & Australia (419) \\
\hline $39 *$ & $\begin{array}{l}\text { Ramakrishnan et al. } \\
\text { (2012) }\end{array}$ & IT & $\begin{array}{l}\text { "Institutional Isomorphism; Competitive } \\
\text { Pressure" }\end{array}$ & USA (63) \\
\hline 40 & Mathew (2012) & TaM & $\begin{array}{l}\text { "Size; Management; Access; Affordability; } \\
\text { Decision Support; Task Complexity; } \\
\text { Technology Familiarity; Quantitative } \\
\text { Skills" }\end{array}$ & India (-) \\
\hline 41 & $\begin{array}{l}\text { Dawson and Van Belle } \\
\text { (2013) }\end{array}$ & TRA & $\begin{array}{l}\text { "Management Support; Champion; } \\
\text { Resources; User Participation; Data } \\
\text { Quality" }\end{array}$ & South Africa (-) \\
\hline $42 *$ & Han and Farn (2013) & TEU & $\begin{array}{l}\text { "Perceived Usefulness; Confirmation; } \\
\text { Satisfaction; Habit; Structural }\end{array}$ & Taiwan (117) \\
\hline
\end{tabular}




\begin{tabular}{|c|c|c|c|c|}
\hline No & Author(s) & Theories & Factors & $\begin{array}{c}\text { Countries and } \\
\text { Sampling }\end{array}$ \\
\hline $43 *$ & $\begin{array}{l}\text { Grublješič and Jaklič } \\
(2015)\end{array}$ & STROBE & $\begin{array}{l}\text { Empowerment; Psychological } \\
\text { Empowerment" } \\
\text { "Individual Characteristics; BIS Quality } \\
\text { Characteristics; Organizational Factors; } \\
\text { Macro-Environmental Characteristics; } \\
\text { Performance Perceptions; Result } \\
\text { Demonstrability; Effort Perceptions; Social }\end{array}$ & Slovenia (-) \\
\hline $44^{*}$ & Visinescu et al. (2017) & BJSDCM & $\begin{array}{l}\text { Influence; Facilitating Conditions" } \\
\text { "Problem Space Complexity; Information } \\
\text { Quality; Perceived Decision Quality" }\end{array}$ & USA (60) \\
\hline
\end{tabular}

* means studies were conducted with individual of analysis (no * means studies were conducted with organizational unit of analysis)

Notes (Theories): Bagozzi, Dholakia and Basuroy model (BDB); Burton et al. dimensions Clark's model (BJSDCM); Diffusion of innovation theory (DOI); Expectation-confirmation Model of IS (ECMoIS); Expectancy Theory (ET); Gorry et al. Morton MIS framework (GSM); Integrative Model of IT Value (IMoITV); Information processing theory (IPT); Institution theory (IT); IS continuance model (ISCM); Motivational theory (MT); Nomological net model (NNM); Resource based view (RBV); Social exchange theory (SET); Strategic orientation of business enterprise framework (STROBE); Technology Acceptance Model (TAM); Technology adoption model (TaM); Theory of effective use (TEU); Theory of effective use (TES); Technology, Organization, Environment (TOE); Theory of Planned Behavior (TPB); Technology to Performance Chain model (TPC); Theory of Reasoned action (TRA); Unified Theory of acceptance and use of technology (UTAT); Value-chain activities framework by Porter(VCAFP); Wixom \& Waston framework (WWF)

Visible from Table 1, researchers in the past two decades highly relied on TAM to measure the BI adoption and largely ignored other ideas. Of the 44 studies, 15 (34\%) used the TAM and its modification as their theoretical framework. Kim et al. (2007) suggested that TAM is too old and not sufficient enough to explain the adoption of new information and communication technology such as AI and BI. Therefore, researchers can try not to rely on TAM to measure the adoption of BI because using a single point of view is unable to reflect the view more comprehensively. Researchers can make use of TAM as a foundation to further explore and develop technology acceptance theories in the next decade.

\section{Main antecedents}

Researchers suggested a lot of information technology adoption theories on BI system adoption such as TAM, UTAUT, and DOI. Although these frequently used theories are reliable enough and have been adopted by many information system researchers, it only focusses on the positive impacts of technology use exclusively. This study classified key antecedents from literature related to BI adoption in the past two decades into two types: positive stimulus and negative stimulus. Figure 1 illustrates the classification results. There are about 30 positive stimuli and 1 negative stimulus from the literature related to BI adoption. It was found that prior research studies frequently focused on the influence of positive stimulus in BI adoption research, while there were very limited studies focused on the impact of negative stimulus in BI adoption. Therefore, investigation of negative stimulus in BI adoption is necessary in order to understand the adoption of BI comprehensively. Researchers can consider more negative factors in future studies related to BI adoption.

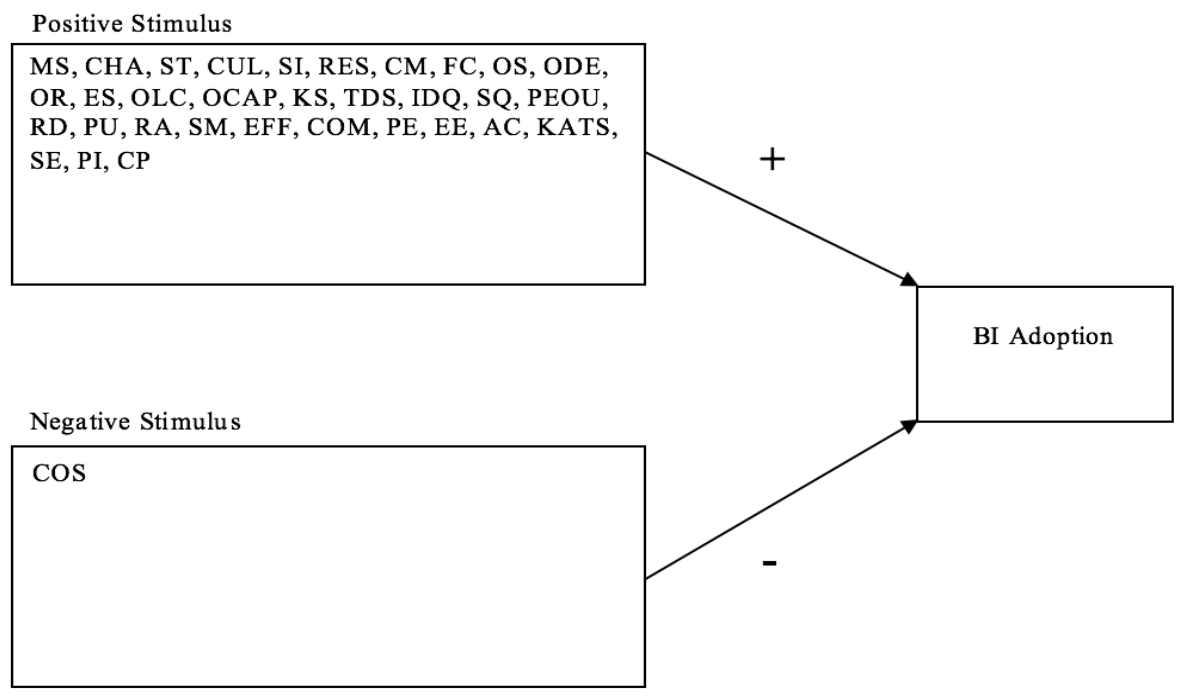

Figure 1. Classification of key antecedents to influence the adoption of BI

Note: Management support (MS), Champion (CHA), Support and training (ST), Cost (COS), Culture (CUL), Social influence (SI), Resources (RES), Change management (CM), Facilitating Conditions (FC), Organization size (OS), Competitive pressure (CP), Organizational data environment (ODE), 
Organizational readiness (OR), external support (ES), Organizational BI capabilities (OCAP), Organizational learning climate (OLC), Knowledge sharing (KS), Technology driven strategy (TDS), Information/ Data Quality (IDQ), System quality (SQ), Perceived ease of use (PEOU), Result demonstrability (RD), Perceived Usefulness (PU), Relative advantages (RA), BI system maturity (SM), BIS effectiveness (EFF), Compatibility (COM), Performance expectancy (PE), effort expectancy (EE), Absorptive capacity (AC), Team IT knowledge and technical skills (KATS), Self-efficacy (SE), Personal innovativeness (PI)

\section{CONCLUSION}

This study reviewed 44 research articles published on the adoption of BI between the year 2000 and the first quarter of 2020. The findings first indicate that the analysis of BI adoption literature is not comprehensive enough. Researchers in the past two decades commonly relied on TAM and its modifications to measure the adoption of BI. The finding also indicates that there are limited research studies on the negative stimulus of BI adoption.

For the theoretical significance, this study proposes the agenda for continued research in the area of BI adoption that targets identified gaps in the literature: (1) Investigation of negative stimulus in BI adoption is necessary in order to understand the BI adoption comprehensively. Researchers can consider more negative factors in future studies related to BI adoption. (2) Researchers can try not to rely on TAM to measure the adoption of BI because using a single point of view is unable to reflect the view more comprehensively. Also, TAM is too old and not sufficient enough to explain the adoption of new information and communication technology such as AI and BI. Researchers can make use of TAM as a foundation to further explore and develop technology acceptance theories in the next decade. For practical significance, $\mathrm{BI}$ vendors can understand the barriers and factors influencing BI adoption in an organization and try to adjust their BI products in order to attract more organizations to adopt BI in near future.

There are some limitations of this study and it offers opportunities for additional research. Firstly, the searching process of this study focused on BI adoption or acceptance, where some relevant and important research articles might be excluded. Secondly, the core of this study is to review the acceptance or adoption of BI in the past two decades, in which the factors in the post-adoption stage were excluded.

\section{REFERENCES}

Ahmad, A., Ahmad, R. \& Hashim, K.F. (2016). Innovation traits for business intelligence successful deployment. Journal of Theoretical \& Applied Information Technology, 89(1).

Arefin, M.S., Hoque, M.R. \& Bao, Y. (2015). The impact of business intelligence on organization's effectiveness: an empirical study. Journal of Systems and Information Technology, 17(3), 263.

Arnott, D., Lizama, F. \& Song, Y. (2017). Patterns of business intelligence systems use in organizations. Decision Support Systems, 97, 58-68.

Bach, M.P., Čeljo, A. \& Zoroja, J. (2016). Technology Acceptance Model for Business Intelligence Systems: Preliminary Research. Procedia Computer Science, 100, 995-1001.

Barney, J. (1991). Firm Resources and Sustained Competitive Advantage. Journal of Management, 17(1), 99-120.

Boonsiritomachai, W., McGrath, G.M. \& Burgess, S. (2016). Exploring business intelligence and its depth of maturity in Thai SMEs. Cogent Business \& Management, 3(1).

Brockmann, T., Stieglitz, S., Kmieciak, J. \& Diederich S. (2012). User acceptance of mobile business intelligence services. 15th International Conference on Network-Based Information Systems (NBiS), 861-866.

Chang, Y.-W., Hsu, P.-Y. \& Shiau, W.-L. (2014). An empirical study of managers' usage intention in BI. Cognition, Technology \& Work, 16(2), 247-258.

Chang, Y.-W., Hsu, P.-Y. \& Wu, Z.-Y. (2015). Exploring managers' intention to use business intelligence: the role of motivations. Behaviour \& Information Technology, 34(3), 273-285.

Chang, Y.-W., Hsu, P.-Y., Shiau, W.-L. \& Wu, Z.-Y. (2017). The effects of personality traits on business intelligence usage: A decision-making perspective. Malaysian Journal of Library \& Information Science, 20(2).

Davis, F. D., Bagozzi, R. P., \& Warshaw, P. R. (1989). User acceptance of computer technology: a comparison of two theoretical models. Management Science, 35(8), 982-1003.

Dawson, L. \& Van Belle, J.-P. (2013). Critical success factors for business intelligence in the South African financial services sector. South African Journal of Information Management, 15(1), 1-12.

Dresner Advisort Services (2017). 2017 Small and Mid-Sized Enterprise Business Intelligence Market Study. Retrieved from: https://www.forbes.com/sites/louiscolumbus/2017/10/08/small-businesses-are-the-real-mvps-of-analytics-and-bigrowth/\#60de9e306ca4

Dresner Advisort Services (2018). 2018 Small and Mid-Sized Enterprise Business Intelligence Market Study. Retrieved from: https://softwarestrategiesblog.com/category/business-intelligence/

Elbashir, M.Z., Collier, P.A. \& Davern M.J. (2008). Measuring the effects of business intelligence systems: The relationship between business process and organizational performance. International Journal of Accounting Information Systems, 9(3), 135-153.

Fink, L., Yogev, N. \& Even, A. (2017). Business intelligence and organizational learning: An empirical investigation of value creation processes. Information \& Management, 54(1), 38-56.

Foshay, N., Taylor, A. \& Mukherjee, A. (2014). Winning the hearts and minds of business intelligence users: The role of metadata. Information Systems Management, 31(2) 167-180.

Gorla N. (2003). Features to consider in a data warehousing system. Communications of the ACM, 46(11), 111-115.

Grublješič, T., Coelho, P.S. \& Jaklič, J. (2014). The Importance and Impact of Determinants Influencing Business Intelligence Systems Embeddedness. Information Systems, 15(1).

Grublješič, T. \& Jaklič, J. (2015). Conceptualization of the business intelligence extended use model. Journal of Computer Information Systems, 55(3), 72-82. 
Han, Y. \& Farn, C. (2013). A study on the effects of empowerment and habit on continuance usage of pervasive business intelligence systems. 46th Hawaii International Conference on System Sciences (HICSS), 3768-3777.

Han, Y.-M., Shen, C.-S. \& Farn, C.-K. (2016). Determinants of continued usage of pervasive business intelligence systems. Information Development, 32(3), 424-439.

Hart, M., Esat, F., Rocha, M. \& Khatieb, Z. (2007). Introducing Students to Business Intelligence: Acceptance and Perceptions of OLAP Software. Informing Science \& Information Technology, 4.

Hart, M. \& Porter, G. (2004). The impact of cognitive and other factors on the perceived usefulness of OLAP. Journal of Computer Information Systems, 45(1), 47-56.

Hong, S., Katerattanakul, P., Hong, S.-K. \& Cao, Q. (2006). Usage and perceived impact of data warehouses: A study in Korean financial companies. International Journal of Information Technology \& Decision Making, 5(2), 297-315.

Hou, C.-K. (2012). Examining the effect of user satisfaction on system usage and individual performance with business intelligence systems: An empirical study of Taiwan's electronics industry. International Journal of Information Management, 32(6), 560573.

Hou, C.-K. (2013). Investigating factors influencing the adoption of business intelligence systems: an empirical examination of two competing models. International Journal of Technology, Policy and Management, 13(4), 328-353.

Hou, C.-K. (2014). Exploring the user acceptance of business intelligence systems in Taiwan's electronics industry: applying the UTAUT model. International Journal of Internet and Enterprise Management, 8(3), 195-226.

Hou, C.-K. (2015). Understanding business intelligence system continuance intention An empirical study of Taiwan's electronics industry, Information Development, 32(5), 1359-1371.

Işık, Ö., Jones, M.C. \& Sidorova, A. (2013). Business intelligence success: The roles of BI capabilities and decision environments. Information \& Management, 50(1), 13-23.

Jaklič, J., Grublješič, T. \& Popovič, A. (2018). The role of compatibility in predicting business intelligence and analytics use intentions. International Journal of Information Management, 43, 305-318.

Jiang, Y. (2009). A conceptual framework and hypotheses for the adoption of e-business intelligence. ISECS International Colloquium in Computing, Communication, Control, and Management, 558-561.

Kohnke, O., Wolf, T.R. \& Mueller, K. (2011). Managing user acceptance: an empirical investigation in the context of business intelligence standard software. International Journal of Information Systems and Change Management, 5(4), 269-290.

Kim, H.-W., Chan, H. C. \& Gupta, S. (2007). Value-based Adoption of Mobile Internet: An empirical investigation. Decision Support Systems, 43(1), 111-126.

Kositanurit, B., Osei-Bryson, K.-M. \& Ngwenyama, O. (2011). Re-examining information systems user performance: Using data mining to identify properties of IS that lead to highest levels of user performance. Expert Systems with Applications, 38(6), 7041-7050.

Lautenbach, P., Johnston, K. \& Adeniran-Ogundipe, T. (2017). Factors influencing business intelligence and analytics usage extent in South African organisations. South African Journal of Business Management, 48(3), 23-33.

Li, X., Hsieh, J.P.-A. \& Rai, A. (2013). Motivational differences across post-acceptance information system usage behaviors: An investigation in the business intelligence systems context. Information systems research, 24(3), 659-682.

Mathew, S.K. (2012). Adoption of business intelligence systems in Indian fashion retail. International Journal of Business Information Systems, 9(3), 261-277.

Popovič, A., Puklavec, B. \& Oliveira, T. (2019). Justifying business intelligence systems adoption in SMEs: Impact of systems use on firm performance. Industrial Management \& Data Systems, 119(1), 210-228.

Puklavec, B., Oliveira, T. \& Popovic, A. (2014). Unpacking business intelligence systems adoption determinants: An exploratory study of small and medium enterprises. Economic and Business Review for Central and South-Eastern Europe, 16(2), 185.

Puklavec, B., Oliveira, T., Popovič, A. (2017). Understanding the determinants of business intelligence system adoption stages: an empirical study of SMEs. Industrial Management \& Data Systems, 118(1), 236-261.

Ramakrishnan, T., Jones, M.C. \& Sidorova, A. (2012). Factors influencing business intelligence (BI) data collection strategies: An empirical investigation. Decision Support Systems, 52(2), 486-496.

Ramamurthy, K.R., Sen, A. \& Sinha, A.P. (2008). An empirical investigation of the key determinants of data warehouse adoption. Decision support systems, 44(4), 817-841.

Richards, G., Yeoh, W., Chong, A.Y.L. \& Popovič, A. (2019). Business intelligence effectiveness and corporate performance management: an empirical analysis. Journal of Computer Information Systems, 59(2), 188-196.

Rogers, E. M. (1962). Diffusion of Innovations (5th Ed.). New York, the Free Press.

Torres, R., Sidorova, A. \& Jones, M.C. (2018). Enabling firm performance through business intelligence and analytics: A dynamic capabilities perspective. Information \& Management, 55(7), 822-839.

Tornatzky, L.G. and Fleischer, M. (1990). The Process of Technology Innovation. Lexington: Lexington Books.

Trieu, T. (2013). Extending the theory of effective use: The impact of enterprise architecture maturity stages on the effective use of business intelligence systems. Thirty Fourth International Conference on Information Systems, Milan.

Venkatesh, V., Morris, M. G., Davis, G. B., \& Davis., F. D. (2003). User acceptance of information technology: Toward a unified view. MIS Quarterly, 27(3), 425-479.

Visinescu, L.L., Jones, M.C. \& Sidorova, A. (2017). Improving Decision Quality: The Role of Business Intelligence. Journal of Computer Information Systems, 57(1), 58-66.

Yoon, T.E., Ghosh, B. \& Jeong, B.-K. (2014). User acceptance of business intelligence (BI) application: Technology, individual difference, social influence, and situational constraints. 7th Hawaii International Conference on System Sciences (HICSS), 3758-3766.

Zhao, Z., Navarrete, C. \& Iriberri, A. (2012). Open source alternatives for business intelligence: Critical success factors for adoption. AMCIS 2012, 29. 


\section{AUTHOR'S BIOGRAPHY}

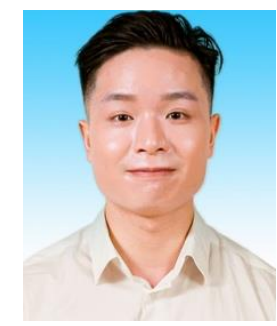

WONG Chi Tin is a PhD student in the Graduate School of Business (GSB) of Universiti Sains Malaysia. His current research focuses on Business Intelligence system and Technology Management.

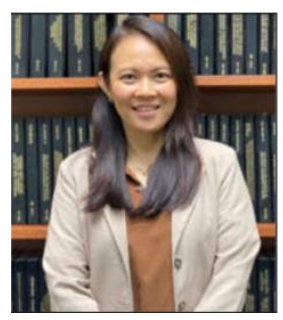

Dr Cheng Ling Tan is an associate professor and deputy dean of the Graduate School of Business at the Universiti Sains Malaysia. She provides lectures on operations management and supervises postgraduate students in the field of innovations and operations management. Her research has been cited in many international journals.

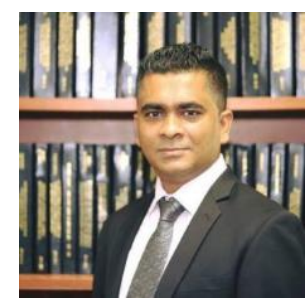

Dr. Imran Mahmud is currently working as Head and Associate Professor at Department of Information Technology \& Management at Daffodil International University, Bangladesh. Previously, Dr. Imran worked as a senior lecturer at Graduate School of Business in Universiti Sains Malaysia. 